\title{
Antiretroviral Therapy (ART): Evaluation of Art's Perception among People Living with HIV/AIDS in South Western Nigeria
}

\section{Oluseye Ademola Okunola*}

Obafemi Awolowo University, Nigeria

\begin{abstract}
ART has become the mainstay in the management of HIVIAIDS worldwide as it has considerably reduced the mortality and morbidity that would have been associated with this disease. The ART however, has transformed the perception of HIVIAIDS from a fatal incurable disease to a manageable chronic illness. The study assessed PLWHA's perception of ART in a tertiary hospital in south western Nigeria.
\end{abstract}

Mixed methods were used to assess the perceptions from the respondents between 18 and 60 years with the aid of structured questionnaire, Focus group discussions and in-depth interviews. Quantitative data were analyzed using percentages, frequency distributions and chi-square while qualitative data were thematically analysed.

The study revealed a positive perception of ART among the respondents which was about $86.3 \%$ as they perceived positive effects of the ART on their health. Furthermore the study was able to identify, improved health status and fear of drug resistance as their major positive perception towards ART from the interview as these were elicited to have contributed to the clients' adherence to ART.

The study in its entirety revealed an overall positive perception to ART among them with the following determinants as factors enhancing the positivity: sex, age, marital status and level of education.

\section{Keywords: ART; HIV/AIDS; PLWHA}

\section{Introduction}

The scourge of Human Immunodeficiency Virus/Acquired Immunodeficiency Diseases (HIV/AIDS) with the development of antiretroviral drugs in its management has gone a long way to make it a chronic manageable disease [1]. The development and widespread use of antiretroviral therapy (ART) as the treatment of choice in HIV has improved significantly the health conditions of HIV positive individuals who could have untimely death. The ART however, has transformed the perception of HIV/AIDS from a fatal incurable disease to a manageable chronic illness [2]. The treatment causes improvement in immunologic status and reduction in the viral load [3] which consequently reduces the incidence of hospitalization and mortality. Perception is concerned with people's beliefs that they can exert control over their own motivation, thought processes, emotional states and patterns of behavior [4]. However, negative perceptions of the efficacy of ART and its effects and could act as barriers and be preventing adherence. Patients' beliefs and behaviours play an important role in adherence. Studies have shown that patient beliefs about illness and the efficacy of the treatment regime affect adherence [5]. Several researchers have tried to look at those factors ranging from socio-economical issues, environmental factors, and patient-doctors interaction among PLWHA affecting their ART, but not much attention have been paid to the influence of personal (client's perception) on this issue. This is the gap that this research intends to fill.

\section{Conceptual Framework}

Conceptual framework for evaluation of ART's perception among PLWHA. The conceptual framework presented in Figure 1 above explained the roles of individual factors (timely taken of medication, improved health status, fear of drug resistance) and various sociodemographic variables like age, sex, marital status, level of education and level of income on clients' perception to ART.

\section{Objective}

To evaluate people living with HIV/AIDS' perception of antiretroviral therapy in the study area.

\section{Methodology}

\section{Study location}

The study was conducted in the Institute of Human Virology of Nigeria which is situated inside the premises of the teaching hospital in Ile-Ife. It was conducted among the clients currently receiving ART there. This institution has catchment of patients from Ondo, Osun and Ekiti states. The choice of the study location is as a result of the center being a referral center and at the same time the only place where ART is been carried out according to the national guideline on management of HIV/AIDS patients in Ile-Ife and its environs. This center is selected as patients diagnosed of HIV from various neighboring communities are referred to this center for management hence having a wide distribution of clients from various zones.

\section{Research design}

The study design was cross-sectional and both qualitative and quantitative research methods were adopted. Clients' perceptions were assessed from sets of questions that were scaled on the questionnaire.

*Corresponding author: Oluseye Ademola Okunola, Senior Medical Officer, Medical and Health Services, Ile-lfe,Obafemi Awolowo University, Osun 220005, Nigeria, Tel: +2347039086791; E-mail: spancho2001@yahoo.com

Received December 08, 2016; Accepted December 24, 2016; Published December 31, 2016

Citation: Okunola OA (2017) Antiretroviral Therapy (ART): Evaluation of Art's Perception among People Living with HIVIAIDS in South Western Nigeria. J AIDS Clin Res 8: 650. doi: 10.4172/2155-6113.1000650

Copyright: (C) 2017 Okunola OA. This is an open-access article distributed unde the terms of the Creative Commons Attribution License, which permits unrestricted use, distribution, and reproduction in any medium, provided the original author and source are credited. 


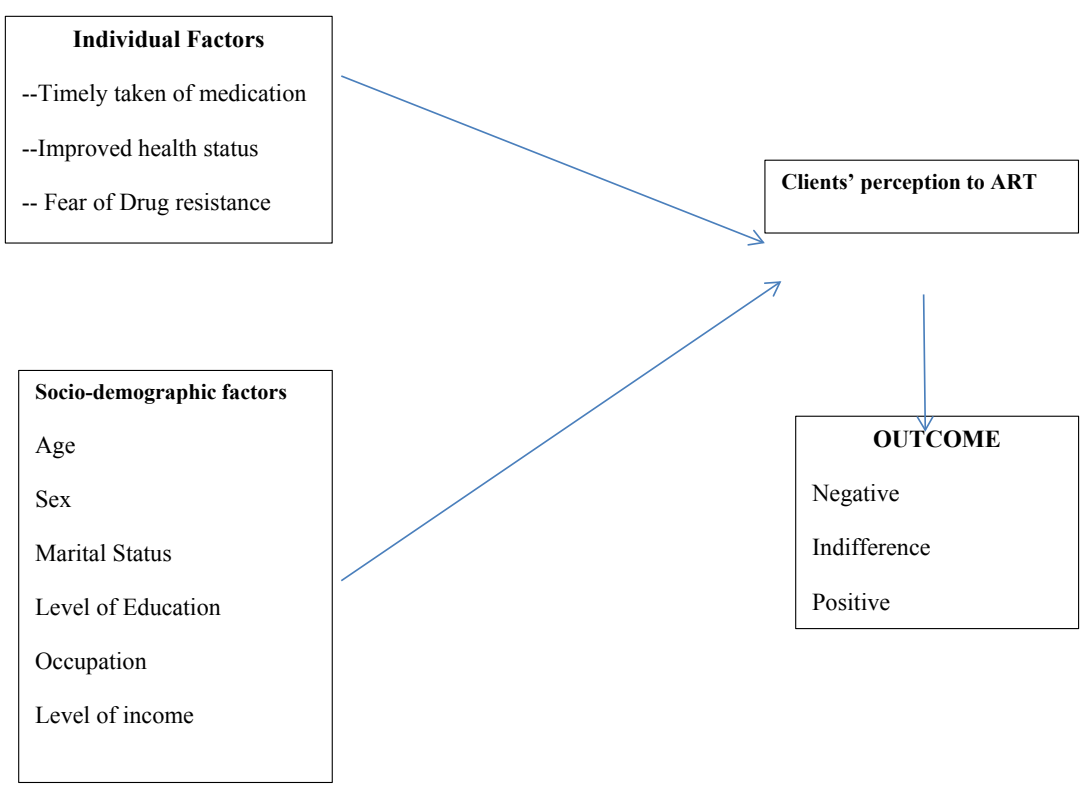

Figure 1: Conceptual framework.

\section{Population and sample size}

The study population was 3007 patients (male and female) between the ages of 18 and 60 years who have been receiving ARV drugs for over six months before the commencement of this study. Pregnant women, children and any other patients with other morbidities were not included in the study.

Sampling size was determined using the formula

$\mathrm{n}(\mathrm{f})=\mathrm{n} / 1+(\mathrm{n} / \mathrm{N})$

$\mathrm{n}=\mathrm{z}^{2} \mathrm{pq} / \mathrm{d}^{2}$

where $\mathrm{z}=$ standard deviation 1.96

$\mathrm{p}=$ prevalence of adherence in southwest is $44 \%=0.44$

$\mathrm{q}=$ failure rate $=1-\mathrm{p}=1-0.44=0.56$

$\mathrm{d}=$ level of significance $=0.05$

$\mathrm{N}=$ study population $=3,007$

Hence the sample size calculated is 336 . As such 336 copies of questionnaire were administered on respondents. Also three in-depth interviews were conducted with a nurse, a doctor and a pharmacist.

\section{Sampling technique}

The sample for the study comprised of male and female clients who have been on ART for more than six months and between the ages of 18 to 60 years. One out of every tenth patients was systematically selected as they presented on each clinic days and were recruited until the desired sample size was achieved. These constituted the patients that were administered questionnaires. These participants had been on antiretroviral drugs for more than six months prior to the study and were selected using systematic sampling technique in which every 10th person was selected for the study until the sample size was reached. The respondents were reached in the Infectious Disease Unit. Also two focus group discussion sessions were held with 10 males and 10 females living with HIV and currently on ART. These groups were purposively selected based on their being on ART for more than one year. Furthermore, in-depth interviews were conducted on three purposively selected healthcare givers (an experienced nurse, a doctor and a pharmacist) in the clinic. All the interviews were conducted at the clinic on the clinic days. For the collection of qualitative data, interview guides were used to conduct the FGD and in-depth interviews.

\section{Research instruments}

The research instruments for this study were comprised of structured questionnaire. Each questionnaire comprised two sections namely; Sections A and B. Section A contained socio-demographic variables. This section was designed to provide information on respondent's sociodemographic variables such as age, sex, marital status among others. Section B contained questions on client's perception of ART. Also interview guide was used to collect information from the healthcare providers on the assessment of ways their clients perceived the ART. Focus group discussion guide was also used to collect information from the respondents. Section A collected information on demographic variables. The questionnaires were administered to the respondents at the clinic on their clinic days in the hospital while the interview and focus discussion groups were conducted in the consulting room after the end of the clinic for the day.

\section{Method of data collection}

Several visits to the clinic and interaction with health workers and PLWHA indicated that there were about 3,000 PLWHA. Staff and patients were favorably disposed to participating in the study.

Data were collected at the clinic by the researcher. In order for the data collection to be hitch free, permission was sought and obtained from the director of the Institute. Structured questionnaire were administered to the respondents. Interviews were conducted with the aid of an interview guide. Also two focus group discussion sessions were conducted for 10 males and 10 females with the aid of the focus group discussion guide. The interviews were conducted and audio-taped by the researcher.

\section{Data analysis}

The analysis of quantitative data was done in three stages. Firstly 
the information obtained from the field was edited; the copies of questionnaire were thoroughly checked to correct all inconsistencies in responses by the respondents. This was done in form of field editing, that is, checking for mistakes and omissions in recording of information while on the field. Secondly, data analysis was preceded by data-coding and data-entry and analyzed using Statistical package for social sciences version 20. Data were analyzed using descriptive statistics. The descriptive data were presented in the form of frequency distribution and percentages. The data were analyzed in themes as each objective formed a theme. The audio responses were transcribed and verbatim quotations were utilized to describe the responses from the qualitative method.

\section{Ethical consideration}

Before the commencement of the study, the purpose of the study was explained to the respondents, assuring them of the confidentiality of their responses and identities. They were also assured that they would not come to any harm as a result of participating in the study. Also their consent was sought and obtained prior to participation. Also, Ethical permission for the study was obtained from the Ethics and Research committee of OAUTHC, Ile-Ife.

\section{Results}

Firstly, univariate analyses presented the socio-demographic characteristics of the respondents using frequency distribution and percentages. The variables presented are sex, age, marital status, ethnic affiliation, religion, level of education, occupation, average monthly income, place of residence and people whom they are residing with. In all, three hundred and thirty six (336) copies of questionnaire were administered in the clinic but three hundred and twenty nine (329) were retrieved for analysis. The response rate is about $98 \%$.

\section{Socio-demographic characteristics of respondents}

Table 1 presents the distribution of the socio-demographic characteristics of the respondents such as sex, age, marital status, ethnic affiliation, religion, level of education, occupation, average monthly income, place of residence and people whom they are residing with. This gives a comprehensive picture of the respondents for this study. Considering the sex distribution of the respondents from Table 1, it was observed that female respondents constitute a larger percentage (64.4\%) than the male (35.6\%). On the basis of age, almost half $(50.2 \%)$ of the respondents fall within the reproductive age of 30 to 40years, while $27.2 \%$ fall within 41 to 50 years and $22.6 \%$ are of more than 50 years. Data on marital status showed that $75.7 \%$ are married while $8.5 \%$ are single with $1.8 \%$ being separated. From the table it could be observed that $95.5 \%$ are of the Yoruba ethnicity, this is probably due to the location of the health facility which is domiciled in the southwestern part of the country where the Yoruba ethnic dominate. Only $0.9 \%$ is of the Hausa tribe and $3.6 \%$ belong to the Igbo ethnic distribution. As for the religious affiliation, majority (81.2\%) was Christians and $17.0 \%$ were Muslims while only $1.8 \%$ identified with the traditional religion. It can also be seen that religion permeates all aspects of human life and experience since every respondent indicated being attached to one religious faith or another.

As for the educational level, the result revealed that $53.5 \%$ of them had post-secondary qualification level while $39.5 \%$ attained secondary education and $7.0 \%$ had primary level of education. As regards the type of occupation, those employed in the public sector were $30.7 \%$ and selfemployed respondents were $24.3 \%$. Also employed in the private sector were $13.7 \%$ and only $1.5 \%$ accounted for the unemployed cadre. The

\begin{tabular}{|c|c|c|c|c|c|c|c|}
\hline \multirow{2}{*}{$\begin{array}{l}\text { Socio-Demograph- } \\
\text { ic Characteristics }\end{array}$} & \multirow[t]{2}{*}{ Options } & \multicolumn{2}{|c|}{ Male } & \multicolumn{2}{|c|}{ Female } & \multicolumn{2}{|c|}{ Total } \\
\hline & & $\mathbf{F}$ & $\%$ & $\mathbf{F}$ & $\%$ & $\mathbf{F}$ & $\%$ \\
\hline \multirow{5}{*}{$\begin{array}{l}\text { Age of respond- } \\
\text { ents }\end{array}$} & $15-30$ years & 12 & 1.9 & 15 & 4.6 & 27 & 6.5 \\
\hline & $31-40$ years & 23 & 7.1 & 118 & 36.5 & 141 & 43.7 \\
\hline & $41-50$ years & 36 & 11.1 & 52 & 16.1 & 88 & 27.2 \\
\hline & $51-60$ years & 49 & 15.2 & 24 & 7.4 & 73 & 22.6 \\
\hline & Total & 120 & 35.3 & 209 & 64.7 & 329 & 100.0 \\
\hline \multirow[t]{7}{*}{ Marital Status } & Single & 11 & 3.3 & 17 & 5.2 & 28 & 8.5 \\
\hline & Married & 98 & 29.8 & 151 & 45.9 & 249 & 75.7 \\
\hline & Divorced & 0 & 0.0 & 15 & 4.6 & 15 & 4.6 \\
\hline & Widow & 6 & 1.8 & 20 & 6.1 & 26 & 7.9 \\
\hline & Widower & 2 & 0.6 & 3 & 0.9 & 5 & 1.5 \\
\hline & Separated & 0 & 0.0 & 6 & 1.8 & 6 & 1.8 \\
\hline & Total & 117 & 35.6 & 212 & 64.4 & 329 & 100.0 \\
\hline \multirow[t]{4}{*}{ Ethnic distribution } & Igbo & 3 & 0.9 & 9 & 2.7 & 12 & 3.6 \\
\hline & Hausa & 0 & 0.0 & 3 & 0.9 & 3 & .9 \\
\hline & Yoruba & 114 & 34.7 & 200 & 60.8 & 314 & 95.5 \\
\hline & Total & 117 & 35.6 & 212 & 64.4 & 329 & 100.0 \\
\hline \multirow[t]{4}{*}{ Religion Affiliation } & Christianity & 82 & 24.9 & 185 & 56.2 & 267 & 81.2 \\
\hline & Islam & 32 & 9.7 & 24 & 7.3 & 56 & 17.0 \\
\hline & Traditional & 3 & 0.9 & 3 & 0.9 & 6 & 1.8 \\
\hline & Total & 117 & 35.6 & 212 & 64.4 & 329 & 100.0 \\
\hline \multirow[t]{4}{*}{ Educational Level } & Primary & 17 & 5.2 & 6 & 1.8 & 23 & 7.0 \\
\hline & Secondary & 49 & 14.9 & 81 & 24.6 & 130 & 39.5 \\
\hline & Post-Secondary & 51 & 15.5 & 125 & 38.0 & 176 & 53.5 \\
\hline & Total & 117 & 35.6 & 212 & & 329 & 100.0 \\
\hline \multirow[t]{9}{*}{ Occupation } & Artisan & 15 & 4.6 & 3 & 0.9 & 18 & 5.5 \\
\hline & $\begin{array}{l}\text { Employed in Private } \\
\text { Sector }\end{array}$ & 18 & 5.5 & 27 & 8.2 & 45 & 13.7 \\
\hline & $\begin{array}{l}\text { Employed in Public } \\
\text { Sector }\end{array}$ & 25 & 7.6 & 76 & 23.1 & 101 & 30.7 \\
\hline & Full Homemaker & 0 & 0.0 & 3 & 0.9 & 3 & .9 \\
\hline & Self Employed & 39 & 11.9 & 41 & 12.5 & 80 & 24.3 \\
\hline & Student & 3 & 0.9 & 0 & 0.0 & 3 & .9 \\
\hline & Trading & 15 & 4.6 & 59 & 17.9 & 74 & 22.5 \\
\hline & Unemployed & 2 & 0.6 & 3 & 0.9 & 5 & 1.5 \\
\hline & Total & 117 & 35.6 & 212 & 64.4 & 329 & 100.0 \\
\hline \multirow{3}{*}{$\begin{array}{l}\text { Place of Resi- } \\
\text { dence }\end{array}$} & Within Osun State & 77 & 23.4 & 152 & 46.2 & 229 & 69.6 \\
\hline & Outside Osun State & 40 & 12.2 & 60 & 18.2 & 100 & 30.4 \\
\hline & Total & 117 & 35.6 & 212 & 64.46 & 329 & 100.0 \\
\hline \multirow{7}{*}{$\begin{array}{l}\text { Persons with } \\
\text { whom they live }\end{array}$} & Alone & 6 & 1.8 & 12 & 3.6 & 18 & 5.5 \\
\hline & With My Partner & 86 & 2.61 & 126 & 38.3 & 212 & 64.4 \\
\hline & With Parents & 0 & 0.0 & 14 & 4.3 & 14 & 4.3 \\
\hline & With Relatives & 8 & 2.4 & 3 & 0.9 & 11 & 3.3 \\
\hline & With Friends & 5 & 1.5 & 6 & 1.8 & 11 & 3.3 \\
\hline & With my children & 12 & 3.6 & 51 & 15.5 & 63 & 19.1 \\
\hline & Total & 117 & 35.6 & 212 & 64.4 & 329 & 100.0 \\
\hline \multirow[t]{5}{*}{ Income } & 5000 to 20000 & 41 & 21.9 & 58 & 31.0 & 99 & 52.9 \\
\hline & 20001 to 40000 & 12 & 6.4 & 21 & 11.2 & 33 & 17.6 \\
\hline & 40001 to 100000 & 12 & 6.4 & 36 & 19.3 & 48 & 25.7 \\
\hline & more than 100000 & 4 & 2.1 & 3 & 1.6 & 7 & 3.7 \\
\hline & Total & 69 & 36.9 & 118 & 63.1 & 187 & 100.0 \\
\hline
\end{tabular}

Table 1: Distribution of respondents by socio-demographic characteristics.

study revealed that $69.6 \%$ of the respondents receiving treatment in this facility were residing within the state (Osun) while $30.4 \%$ of them were living outside the state. It was gathered that $5.5 \%$ of the PLWHA are living alone and $94.5 \%$ are residing with their partner, relative, children, parents and friends, this could be attributed to a very strong 
family and social support been rendered to them. Lastly from the Table 1 , the average monthly income distribution showed that $52.5 \%$ earned between five thousand to twenty thousand naira, $17.6 \%$ earned between twenty thousand to forty thousand naira while only $3.7 \%$ earned above hundred thousand naira.

\section{Analysis of respondent's perception to ART}

In order to summarize the respondents' perceptions, their responses to section $\mathrm{C}$ of the questionnaire were scored as stipulated on the questionnaire that is (Disagree was scored 1, Somewhat Disagree scored 2, Neutral scored 3, Somewhat Agree scored 4 and Agree scored 5). The resulting scores were cumulated to constitute a measure of respondent's perception of ART. On the measure, the maximum value obtained was 40 while the minimum value was 0 . The mean score obtained for the measure is 33.50 with a standard deviation of 9.10 . The measure was categorized in such a way that any score of 16 or less was considered to be negative perception while scores ranging from 17 to 24 are regarded as been indifferent. Any score that is greater than 24 was regarded as positive perception. The categories were then given a descriptive analysis and the result is presented in Table 2. From the table it showed that $86.3 \%$ of the PLWHA that were examined have a very positive perception of ART while $3.6 \%$ negatively perceived ART and only $10.0 \%$ were indifferent.

\section{Reasons for clients' perceptions}

Concerning the various perception of ART by PLWHA, it was noted from the Table 3 below that $90.0 \%$ of the respondents opined to not missing a dose nor taking it lately or incorrectly for the medication to work best, while $69.9 \%$ of the respondents agreed that the medication they use have a positive effect on their health, however about $30.7 \%$ disagree on the basis that some ARV drugs have to be taken on an empty stomach and others may be taken with food. Also $84.8 \%$ of the respondents agreed at all levels that the time at which the medication is taken will influence its effectiveness but only $11.5 \%$ disagreed to this while $1.8 \%$ remained indifferent. Meanwhile, $85.4 \%$ of the participants revealed that drug resistance develops when their ARV are missed or taken lately or incorrect with $75.4 \%$ of them fully aware that they would have to take the drugs for the rest of their life. In addition, the Table 3 also revealed that $78.1 \%$ of the examined PLWHA agreed that if they do not take the medication exactly as instructed the HIV in their

\begin{tabular}{|l|c|c|}
\hline & Frequency & Percentage \\
\hline Negative & 12 & 3.6 \\
\hline Indifferent & 33 & 10.0 \\
\hline Positive & 284 & 86.3 \\
\hline Total & 329 & 100.0 \\
\hline
\end{tabular}

Table 2: Respondents' perception of ART. body will become resistant to HIV medication as only $1.8 \%$ of them remained indifferent to this and $10.9 \%$ totally disagreed to it. In the overall assessment it could be deduced that they have a very strong/ positive disposition to ART.

This finding was corroborated by interviewed respondents in the following extracts

\section{Extract 1: Response from one of the PLWHA}

Improvement in respondents' health status was identified as one of the reasons for adhering to ART as can be evidenced from these excerpts:

"I know, before my coming here I was very sick and have been taking some drugs with nil improvement, I see much improvement. All those irritations on my skin have disappeared and as I was lean before, but now I have put on weight, so the drug is really working" (FGD2, Male, 35 years)

\section{Extract 2: Response from one of the PLWHA}

'It's working very well as my body is ok and I don't fall sick like before' (FGD2, Female, 51 years)

\section{Extract 3: In-depth Interview with health worker (Nurse)}

'generally they are not doing bad, we only have some few defaulters, at the time they are coming in maybe they are very sick, we place they them on ART after counselling, some of them after getting well decide to default'

\section{Extract 4: In-depth interview with health worker (A Medical} Doctor)

'Some do adhere but some don't adhere strictly, some ask whenever they miss their doses that can they still take it maybe 30 min after the normal or ideal time, by this you know that they are not adhering well. But generally they do adhere very well, except very few'

\section{Extract 5: In-depth interview with health worker (A} Pharmacist)

'invariably they are doing very well, I won't be able to score them $100 \%$, I will give them $90 \%$ because they themselves have really seen reasons to adhere very seriously'

To further corroborate the perception of uptake of ART by the respondents, the health workers who are involved in the direct care for these patients fully supported that majority of them have a very positive perception of ART.

From the interviewees' responses it could be affirmed that most PLWHA in this study have a very positive perception of ART they are taking.

\begin{tabular}{|c|c|c|c|c|c|c|c|c|c|c|c|c|}
\hline \multirow{2}{*}{ Perception statements } & \multicolumn{2}{|c|}{ Disagree } & \multicolumn{2}{|c|}{$\begin{array}{c}\text { Somewhat } \\
\text { disagree }\end{array}$} & \multicolumn{2}{|c|}{ Neutral } & \multicolumn{2}{|c|}{$\begin{array}{l}\text { Somewhat } \\
\text { agree }\end{array}$} & \multicolumn{2}{|c|}{ Agree } & \multicolumn{2}{|c|}{$\begin{array}{l}\text { No } \\
\text { response }\end{array}$} \\
\hline & f & $\%$ & $\mathbf{f}$ & $\%$ & f & $\%$ & f & $\%$ & f & $\%$ & f & $\%$ \\
\hline The medication I use have a positive effect on my health & 60 & 18.2 & 12 & 3.6 & 9 & 2.7 & 12 & 3.6 & 230 & 69.9 & 6 & 1.8 \\
\hline $\begin{array}{l}\text { If I do not take the medication exactly as instructed the HIV in my body will become } \\
\text { resistant to HIV medication }\end{array}$ & 36 & 10.9 & 12 & 3.6 & 6 & 1.8 & 12 & 3.6 & 257 & 78.1 & 6 & 1.8 \\
\hline I have to take drugs for the rest of my life & 51 & 15.5 & 6 & 1.8 & 3 & 0.9 & 9 & 2.7 & 248 & 75.4 & 12 & 3.6 \\
\hline Some ARV drugs have to be taken on an empty stomach and others may be taken with food & 95 & 28.9 & 6 & 1.8 & 6 & 1.8 & 12 & 3.6 & 201 & 61.1 & 9 & 2.7 \\
\hline The time at which the medication is taken will influence its effectiveness & 30 & 9.1 & 8 & 2.4 & 6 & 1.8 & 12 & 3.6 & 267 & 81.2 & 6 & 1.8 \\
\hline Missing doses or taking them late or incorrectly will determine if the treatment works & 48 & 14.6 & 5 & 1.5 & 6 & 1.8 & 12 & 3.6 & 249 & 75.7 & 9 & 2.7 \\
\hline For my medication to work best, I should not miss a dose nor take it late or incorrectly & 9 & 2.7 & 6 & 1.8 & 3 & 0.9 & 9 & 2.7 & 296 & 90.0 & 6 & 1.8 \\
\hline Drug resistance develops when my ARV are missed or taken late or incorrectly. & 18 & 5.5 & 3 & 0.9 & 9 & 2.7 & 12 & 3.6 & 281 & 85.4 & 6 & 1.8 \\
\hline
\end{tabular}

Table 3: Reasons for clients' perception. 
Citation: Okunola OA (2017) Antiretroviral Therapy (ART): Evaluation of Art's Perception among People Living with HIV/AIDS in South Western Nigeria. J AIDS Clin Res 8: 650. doi: 10.4172/2155-6113.1000650

Page 5 of 6

\begin{tabular}{|c|c|c|c|c|c|}
\hline \multirow{3}{*}{$\begin{array}{l}\text { Socio-demographic } \\
\text { Characteristics }\end{array}$} & \multicolumn{5}{|c|}{ Level of Perception to ART } \\
\hline & Negative & Indifferent & Positive & Total & $\chi^{2}$ (p value) \\
\hline & Freq $(\%)$ & Freq $(\%)$ & Freq (\%) & Freq $(\%)$ & \multirow{7}{*}{$\begin{array}{c}\chi^{2}=16.625 \\
p(0.011) \\
d f=6\end{array}$} \\
\hline \multicolumn{5}{|l|}{ Age group } & \\
\hline $15-30$ years & $3(0.9)$ & $0(0.0)$ & $18(5.6)$ & $21(6.5)$ & \\
\hline $31-40$ years & $5(5.1)$ & $9(2.8)$ & $127(39.3)$ & $141(43.7)$ & \\
\hline $41-50$ years & $2(0.6)$ & $15(4.6)$ & $71(22.0)$ & $88(27.2)$ & \\
\hline $51-60$ years & $2(0.6)$ & $6(1.9)$ & $65(20.1)$ & $73(22.6)$ & \\
\hline Total & $12(3.7)$ & $30(9.3)$ & $281(87.0)$ & $323(100.0)$ & \\
\hline \multicolumn{6}{|l|}{ Sex } \\
\hline Male & $2(0.6)$ & $18(5.5)$ & $97(29.5)$ & $117(35.6)$ & \multirow{3}{*}{$\begin{array}{c}\chi^{2}=7.305 \\
p(0.026) \\
d f=2\end{array}$} \\
\hline Female & $10(3.0)$ & $15(4.6)$ & $187(56.8)$ & $212(64.4)$ & \\
\hline Total & $12(3.6)$ & $33(10.0)$ & $284(86.3)$ & $329(100.0)$ & \\
\hline \multicolumn{6}{|l|}{ Marital Status } \\
\hline Single & $2(0.6)$ & $3(0.9)$ & $23(7.0)$ & $28(8.5)$ & \multirow{7}{*}{$\begin{array}{c}\chi^{2}=29.310 \\
p(0.001) \\
d f=10\end{array}$} \\
\hline Married & $6(1.8)$ & $30(9.1)$ & $213(64.7)$ & $249(75.7)$ & \\
\hline Divorced & $0(0.0)$ & $0(0.0)$ & $15(4.6)$ & $15(4.6)$ & \\
\hline Widowed & $2(0.6)$ & $0(0.0)$ & $24(7.3)$ & $26(7.9)$ & \\
\hline Widower & $2(0.6)$ & $0(0.0)$ & $3(0.9)$ & $5(1.5)$ & \\
\hline Separated & $0(0.0)$ & $0(0.0)$ & $6(1.8)$ & $6(1.8)$ & \\
\hline Total & $12(3.6)$ & $33(10.0)$ & $284(86.3)$ & $329(100.0)$ & \\
\hline \multicolumn{6}{|l|}{ Ethnic affiliation } \\
\hline Hausa & $0(0.0)$ & $0(0.0)$ & $3(0.9)$ & $3(0.9)$ & \multirow{4}{*}{$\begin{array}{c}\chi^{2}=2.490 \\
p(0.646) \\
d f=4\end{array}$} \\
\hline Igbo & $0(0.0)$ & $0(0.0)$ & $12(3.6)$ & $12(3.6)$ & \\
\hline Yoruba & $12(3.6)$ & $33(10.0)$ & $269(81.38$ & $314(95.4)$ & \\
\hline Total & $12(3.6)$ & $33(10.0)$ & $284(86.3)$ & $329(100.0)$ & \\
\hline \multicolumn{6}{|l|}{ Religion } \\
\hline Christianity & $12(3.6)$ & $21(6.4)$ & $234(71.1)$ & $267(81.2)$ & \multirow{4}{*}{$\begin{array}{c}\chi^{2}=12.463 \\
p(0.014) \\
d f=4\end{array}$} \\
\hline Islam & $0(0.0)$ & $12(3.6)$ & $44(13.4)$ & $56(17.0)$ & \\
\hline Traditional & $0(0.0)$ & $0(0.0)$ & $6(1.8)$ & $6(1.8)$ & \\
\hline Total & $12(3.6)$ & $33(10.0)$ & $284(86.3)$ & $329(100.0)$ & \\
\hline \multicolumn{6}{|l|}{ Level of Education } \\
\hline Primary & $2(0.6)$ & $3(0.9)$ & $18(5.5)$ & $23(7.0)$ & \multirow{4}{*}{$\begin{array}{c}\chi^{2}=18.618 \\
p(0.001) \\
d f=4\end{array}$} \\
\hline Secondary & $8(2.4)$ & $21(6.4)$ & $101(30.7)$ & $130(39.5)$ & \\
\hline Post-Secondary & $2(0.6)$ & $9(2.7)$ & $165(50.2)$ & $176(53.5)$ & \\
\hline Total & $12(3.6)$ & $33(10.0)$ & $284(86.3)$ & $329(100.0)$ & \\
\hline
\end{tabular}

Table 4: Relationship between respondents' perception to ART and Socio-demographic characteristics.

Conversely, only one interviewee was of negative perception on the uptake of ART as he said:

\section{Extract 6: Response from one of the PLWHA}

'not really I just know that it should be taken at the same time on each days' (FGD1, Male, 44 years) (Table 4$).$

\section{Discussion}

In this study, it was indicated that $86.3 \%$, of the respondents had a very strong, positive perception of ART as most of them believe that for the medication to work best, doses of the ARV drugs must not be missed nor taken incorrectly, adequately and at the right time. Almost all the respondents $(86.3 \%)$ had a positive perception of ART and this proportion was higher than those found earlier in similar studies in Southwest Nigeria; $73.9 \%$ in Ibadan by Olowookere et al. and $77 \%$ in treatment centres in Ilesha and Ile-Ife [6,7]. The increment might be due to more awareness about the free treatment and increase in early diagnosing with prompt commencement of ART among them. It was noted during the interview section that good counseling by the counselors in the clinic enhanced them to have a very strong perception of ART. This finding was corroborated by Onyeonoro et al. which revealed a fairly good knowledge and perception of ART among the PLWHA [8]. Also, over $70 \%$ of them were of the opinion that the medications have positive effects on their health. This was further supported by the health care workers interviewed as they rated them more than $90 \%$ effective in their uptake of the ARV medications as they are very committed to the therapy. Furthermore the study was able to identify, improved health status and fear of drug resistance as their major positive perception towards ART from the interview as these were elicited to have contributed to the clients' adherence to ART.

Considering the relationship between the respondents' perception of ART and socio-demographic variables of the respondents: age, sex, marital status, religion, level of education and income level were found to be statistically significant. Perception to ART among the respondents was noticed to be mostly positive in all the variables. A significantly statistically relationship was reported in the age group ( $\left.\chi^{2}=16.625, \mathrm{p}<0.05\right)$ as $31-40$ years which are within the reproductive age groups majorly have a positive perception to ART. Also the female gender among the sex population showed $56.8 \%$ of positive perception to ART which was statistically significant at $\left(\chi^{2}=7.305, \mathrm{p}<0.05\right)$. It was observed during data collection that in every clinic appointment, women were usually more than the men. Other African studies among adult HIV patients in clinic settings also had higher proportions of female respondents and similar average ages according to Potchoo 
Citation: Okunola OA (2017) Antiretroviral Therapy (ART): Evaluation of Art's Perception among People Living with HIV/AIDS in South Western Nigeria. J AIDS Clin Res 8: 650. doi: 10.4172/2155-6113.1000650

et al. and Talam et al. $[9,10]$. In addition, marital status especially among the married group constituted $64.7 \%$ of positive perception to ART with statistically significant $\left(\chi^{2}=29.310, \mathrm{p}<0.05\right)$. Also the relationship between perception and level of education was found to be statistically significant $\left(\chi^{2}=18.618, \mathrm{p}<0.05\right)$ as the respondents with post-secondary educational qualification constituting $50.2 \%$ of the respondents. This was corroborated by Afolabi et al. which showed that higher education was significantly associated with good knowledge about ART [7].

\section{Conclusion}

The study in its entirety revealed an overall positive perception to ART among them with the following determinants as factors enhancing the positivity: sex, age, marital status and level of education.

\section{References}

1. UNAIDS (2010) UNAIDS: Report on the global. HIVIAIDS epidemic 2010. Geneva Switzerland.

2. Palella F, Delaney K, Moorman A, Loveless M, Fuhrer J, et al. (1998) Declining morbidity and mortality among patients with advanced human immunodeficiency virus infection HIV outpatients study investigations. N Engl J Med 338: 853-860.

3. Erb P, Battegay M, Zimmerli W, Rickenbach M, Egger M (2000) Effect of antiretroviral therapy on viral load, CD4 cell count and progression of acquired immunodeficiency syndrome in a community of human immunodeficiency virus-infected cohort study. Arch Intern Med 160: 1134-1140.

4. Wasti S, Simkhada P, Randall J, Freeman J, van Teijlingen E (2012) Factors influencing adherence to antiretroviral treatment in Nepal: A mixed-methods study. PLoS One 7: e35547.

5. Mills E, Nachega J, Buchan I, Orbinski J, Attaran A, et al. (2006) Adherence to antiretroviral therapy in Sub-Saharan Africa and North America: A metaanalysis. JAMA 296: 679-690.

6. Olowookere SA, Fatiregun AA, Adewole IF (2012) Knowledge and attitudes regarding HIVIAIDS and antiretroviral therapy among patients at a Nigerian treatment clinic. J Infect Dev Ctries 6: 809-816.

7. Afolabi MO, ljadunola KT, Fatusi AO, Olasode O (2010) Knowledge of and attitude towards antiretroviral therapy among people living with HIVIAIDS in Nigeria. TAF Prev Med Bull 9: 201-208.

8. Onyeonoro UU, Ebenebe UE, Ibeh CC, Nwamoh UN, Ukegbu AU, et al (2013) Adherence to antiretroviral therapy among people living with human immunodeficiency virus/acquired immunodeficiency syndrome in a tertiary health facility in South Eastern Nigeria. J HIV Hum Reprod 1: 58-63.

9. Potchoo Y, Tchamdja K, Balogou A, Pitche PP, Guissou IP, et al. (2010) Knowledge and adherence to antiretroviral therapy among adult people living with HIV treated in the health care centers of the association "Espoir Vie Togo" in Togo, West Africa. BMC Clin Pharmacol 10: 11.

10. Talam NC, Gatongi P, Rotich J, Kimaiyo S (2008) Factors affecting antiretroviral drug adherence among HIVIAIDS adult patients attending HIVIAIDS clinic at Moi Teaching and Referral Hospital, Eldoret, Kenya. East Afr J Public Health 5: 74-78. 